\title{
Spatially resolving methane emissions in California: constraints from the CalNex aircraft campaign and from present (GOSAT, TES) and future (TROPOMI, geostationary) satellite observations
}

\author{
K. J. Wecht ${ }^{1}$, D. J. Jacob ${ }^{1}$, M. P. Sulprizio ${ }^{1}$, G. W. Santoni ${ }^{1}$, S. C. Wofsy ${ }^{1}$, R. Parker ${ }^{2}$, H. Bösch ${ }^{2}$, and J. Worden ${ }^{3}$ \\ ${ }^{1}$ Department of Earth and Planetary Sciences, Harvard University, Cambridge, MA, USA \\ ${ }^{2}$ Earth Observation Science, Space Research Centre, University of Leicester, Leicester, UK \\ ${ }^{3}$ Jet Propulsion Laboratory/California Institute of Technology, Pasadena, CA, USA
}

Correspondence to: K. J. Wecht (wecht@ fas.harvard.edu)

Received: 9 January 2014 - Published in Atmos. Chem. Phys. Discuss.: 14 February 2014

Revised: 16 May 2014 - Accepted: 30 June 2014 - Published: 14 August 2014

\begin{abstract}
We apply a continental-scale inverse modeling system for North America based on the GEOS-Chem model to optimize California methane emissions at $1 / 2^{\circ} \times 2 / 3^{\circ}$ horizontal resolution using atmospheric observations from the CalNex aircraft campaign (May-June 2010) and from satellites. Inversion of the CalNex data yields a best estimate for total California methane emissions of $2.86 \pm 0.21 \mathrm{Tg} \mathrm{a}^{-1}$, compared with $1.92 \mathrm{Tg} \mathrm{a}^{-1}$ in the EDGAR v4.2 emission inventory used as a priori and $1.51 \mathrm{Tg} \mathrm{a}^{-1}$ in the California Air Resources Board (CARB) inventory used for state regulations of greenhouse gas emissions. These results are consistent with a previous Lagrangian inversion of the CalNex data. Our inversion provides 12 independent pieces of information to constrain the geographical distribution of emissions within California. Attribution to individual source types indicates dominant contributions to emissions from landfills/wastewater $\left(1.1 \mathrm{Tg} \mathrm{a}^{-1}\right)$, livestock $\left(0.87 \mathrm{Tg} \mathrm{a}^{-1}\right)$, and gas/oil $\left(0.64 \mathrm{Tg} \mathrm{a}^{-1}\right)$. EDGAR v4.2 underestimates emissions from livestock, while CARB underestimates emissions from landfills/wastewater and gas/oil. Current satellite observations from GOSAT can constrain methane emissions in the Los Angeles Basin but are too sparse to constrain emissions quantitatively elsewhere in California (they can still be qualitatively useful to diagnose inventory biases). Los Angeles Basin emissions derived from CalNex and GOSAT inversions are $0.42 \pm 0.08$ and $0.31 \pm 0.08 \mathrm{Tg} \mathrm{a}^{-1}$ that the future TROPOMI satellite instrument (2015 launch) will be able to constrain California methane emissions at a detail comparable to the CalNex aircraft campaign. Geostationary satel-
\end{abstract}

lite observations offer even greater potential for constraining methane emissions in the future.

\section{Introduction}

Quantifying greenhouse gas emissions at the national and state level is essential for climate policy. The state of California Assembly Bill 32 (AB32) legislates that state greenhouse gas emissions be brought down to 1990 levels by 2020. The California Air Resources Board (CARB) has identified the importance of reducing methane for complying with $\mathrm{AB} 32$ (CARB, 2013). It provides a statewide methane emission inventory for enforcement of AB32 (CARB, 2011). However, atmospheric observations from surface sites and aircraft suggest that this inventory may be too low by a factor of 2 or more (Wunch et al., 2009; Jeong et al., 2012; Peischl et al., 2012; Wennberg et al., 2012; Santoni et al., 2014a). This is problematic in terms of designing a credible emissions control strategy.

Atmospheric observations play a critical role in measurement, reporting, and verification (MRV) of greenhouse gas emission inventories (NRC, 2010). Surface measurements are limited in space, and aircraft campaigns are limited in time. Satellite observations have the potential for continuous monitoring of emissions if their sensitivity and coverage is sufficient. In Wecht et al. (2014), we present a new capability developed under the NASA Carbon Monitoring System (CMS) to constrain methane emissions at high spatial 
resolution over North America by inversion of satellite observations in an Eulerian framework (GEOS-Chem chemical transport model). Here we apply this capability to estimate the fine-scale distribution of emissions in California by using observations from the CalNex aircraft campaign (MayJune 2010) and from current satellite instruments (GOSAT, TES). We also explore the potential of future satellite instruments (TROPOMI, geostationary).

Santoni et al. (2014a) previously used the CalNex aircraft observations in a Lagrangian inversion of methane emissions for California, optimizing a total of eight source types/regions within the state. They derived an optimized statewide emission of $2.4 \mathrm{Tg} \mathrm{a}^{-1}$, as compared to $1.5 \mathrm{Tg} \mathrm{a}^{-1}$ in the CARB inventory, and attributed most of the underestimate to livestock emissions. Here we use the same CalNex observations as Santoni et al. (2014a) but optimize emissions on the $1 / 2^{\circ} \times 2 / 3^{\circ}\left(\sim 50 \times 50 \mathrm{~km}^{2}\right)$ grid of GEOSChem without prior assumption on source types, thus providing a different perspective and a check on the use of different inversion methodologies.

We then apply our CMS framework to examine the constraints on California methane emissions achievable from satellite observations in comparison to the CalNex observations. Satellites measure methane from solar backscatter spectra in the shortwave infrared (SWIR) and terrestrial radiation spectra in the thermal infrared (TIR). A number of satellite instruments have the capability to observe methane (Table 1). SWIR retrievals are available from SCIAMACHY (2003-2012) and GOSAT (2009-present). TIR retrievals are available from AIRS (2002-present), TES (2004-2011), and IASI (2007-present). SWIR retrievals provide total atmospheric methane columns. TIR retrievals provide vertical profiles but have limited sensitivity to the lower troposphere due to lack of thermal contrast, and this limits their value for detecting regional sources (Wecht et al., 2012).

Our initial CMS application described in Wecht et al. (2014) focused on optimizing methane emissions on the continental scale of North America using SCIAMACHY observations for summer 2004. SCIAMACHY provided highquality observations with high density until 2005 , after which the sensitivity of the instrument degraded (Frankenberg et al., 2011). Current satellite observations are available from GOSAT and TES. As we will see, these observations are too sparse to usefully constrain the distribution of emissions within California. Drastic improvement in our ability to observe methane from space is expected in 2015 with the launch of the SWIR TROPOMI instrument (Veefkind et al., 2012; Butz et al., 2012). TROPOMI will provide daily global coverage with $7 \times 7 \mathrm{~km}^{2}$ nadir resolution. There are also several current proposals for geostationary SWIR observation of methane over North America, drawing on plans for the NASA GEO-CAPE mission (Fishman et al., 2012). Here we will evaluate the potential of these future instruments to constrain the spatial distribution of emissions at the state level by using observation system simulation experiments (OSSEs) for California anchored by our CalNex results.

\section{GEOS-Chem inverse modeling system for methane emissions}

\subsection{Forward model and optimization procedure}

We use the GEOS-Chem chemical transport model (CTM) with $1 / 2^{\circ} \times 2 / 3^{\circ}$ horizontal resolution as the forward model in the inversion to optimize methane emissions on the basis of observed atmospheric concentrations. The inversion seeks an optimal solution for the spatial distribution of methane emissions consistent with both atmospheric observations and a priori knowledge. The a priori is from existing emission inventories. The forward model, F, relates emissions to methane concentrations. Optimization is done by minimizing the Bayesian least-squares cost function, $J$ :

$$
\begin{aligned}
J(\boldsymbol{x}) & =(\mathrm{F}(\boldsymbol{x})-\boldsymbol{y})^{T} \mathbf{S}_{\mathrm{O}}^{-1}(\boldsymbol{F}(\boldsymbol{x})-\boldsymbol{y}) \\
& +\left(\boldsymbol{x}-\boldsymbol{x}_{\mathrm{A}}\right)^{T} \mathbf{S}_{\mathrm{A}}^{-1}\left(\boldsymbol{x}-\boldsymbol{x}_{\mathrm{A}}\right) .
\end{aligned}
$$

Here $y$ is the ensemble of observations arranged in a vector, $\mathbf{S}_{\mathrm{O}}$ is the error covariance matrix of the observation system, $\mathbf{S}_{\mathrm{A}}$ is the error covariance matrix of the a priori emissions, $\boldsymbol{x}$ is a vector of emission scale factors on the $1 / 2^{\circ} \times 2 / 3^{\circ}$ GEOS-Chem grid, and $\boldsymbol{x}_{\mathrm{A}}$ is the corresponding a priori. $\boldsymbol{x}$ has as elements $\boldsymbol{x}_{i}=E_{i} / E_{\mathrm{A}, i}$, where $E_{i}$ and $E_{\mathrm{A}, i}$ are respectively the true and a priori methane emissions for grid square $i$.

Analytical solution of $\mathrm{d} J / \mathrm{d} x=0$ yields the following expression for the optimal estimate $\hat{\boldsymbol{x}}$, its associated error covariance matrix $\hat{\mathbf{S}}$, and the averaging kernel matrix $\mathbf{A}$ that describes the sensitivity of the retrieved emissions to true emissions (Rodgers, 2000):

$\hat{\boldsymbol{x}}=\boldsymbol{x}_{\mathrm{A}}+\mathbf{S}_{\mathrm{A}} \mathbf{K}^{T}\left(\mathbf{K S}_{\mathrm{A}} \mathbf{K}^{T}+\mathbf{S}_{\mathrm{O}}\right)^{-1}\left(\boldsymbol{y}-\mathbf{K} \boldsymbol{x}_{\mathrm{A}}\right)$,

$\hat{\mathbf{S}}^{-1}=\mathbf{K}^{T} \mathbf{S}_{\mathrm{O}}^{-1} \mathbf{K}+\mathbf{S}_{\mathrm{A}}^{-1}$,

$\mathbf{A}=\mathbf{I}_{n}-\hat{\mathbf{S}} \mathbf{S}_{\mathrm{A}}^{-1}$.

Here $\mathbf{K}$ is the Jacobian matrix for the sensitivity of concentrations to emissions calculated with GEOS-Chem, $\mathbf{I}_{n}$ is the identity matrix, and $n$ is the dimension of $\boldsymbol{x}$.

We use GEOS-Chem version 9-01-02 (http://www. geos-chem.org/), driven by GEOS-5 meteorological data from the NASA Global Modeling and Assimilation Office (GMAO). The GEOS- 5 data have $1 / 2^{\circ} \times 2 / 3^{\circ}$ horizontal resolution, 72 vertical levels (including 14 in the lowest $2 \mathrm{~km}$ ), and $6 \mathrm{~h}$ temporal resolution ( $3 \mathrm{~h}$ for surface variables and mixing depths). The simulations are for a nested version of GEOS-Chem with native $1 / 2^{\circ} \times 2 / 3^{\circ}$ resolution for western North America and the adjacent Pacific (26-70 ${ }^{\circ} \mathrm{N}, 110$ $140^{\circ} \mathrm{W}$ ) and $3 \mathrm{~h}$ dynamic boundary conditions from a global simulation with $4^{\circ} \times 5^{\circ}$ resolution. The transport time step 
Table 1. Satellite observations of methane.

\begin{tabular}{|c|c|c|c|c|c|c|c|}
\hline Instrument & $\begin{array}{l}\text { Wavelength } \\
\text { range }\end{array}$ & Launch & $\begin{array}{r}\text { Return time } \\
{\text { [days }]^{\mathrm{a}}}\end{array}$ & $\begin{array}{r}\text { Pixel resolution } \\
{\left[\mathrm{km}^{2}\right]^{\mathrm{b}}}\end{array}$ & Precision & $\begin{array}{r}\text { DOFS for California } \\
\text { emissions }^{\mathrm{c}}\end{array}$ & Reference \\
\hline \multicolumn{8}{|l|}{ Global $^{\mathrm{d}}$} \\
\hline SCIAMACHY & SWIR & $2002^{\mathrm{e}}$ & 6 & $30 \times 60$ & $1.5 \%$ & & Frankenberg et al. (2011) \\
\hline AIRS & TIR & 2002 & 0.5 & $45 \times 45$ & $1.5 \%$ & & Xiong et al. (2008) \\
\hline TES & TIR & $2004^{\mathrm{f}}$ & 16 & $5 \times 8$ & $1 \%$ & $\sim 0$ & Worden et al. (2012) \\
\hline IASI & TIR & 2007 & 0.5 & $50 \times 50$ & $1.2 \%$ & & $\begin{array}{l}\text { Xiong et al. (2013); } \\
\text { Crevoisier et al. (2013) }\end{array}$ \\
\hline GOSAT & SWIR & 2009 & 3 & $\sim 10 \times 10^{\mathrm{g}}$ & $0.6 \%$ & 1.3 & $\begin{array}{l}\text { Parker et al. (2011); } \\
\text { Schepers et al. (2012) }\end{array}$ \\
\hline TROPOMI & SWIR & 2015 & 1 & $7 \times 7$ & $0.6 \%$ & 10.5 & $\begin{array}{l}\text { Veefkind et al. (2012); } \\
\text { Butz et al. (2012) }\end{array}$ \\
\hline \multicolumn{8}{|l|}{ Geostationary } \\
\hline $\begin{array}{l}\text { Full global coverage } \\
\text { r the CalNex period } \\
\text { ROPOMI and GEO- } \\
\text { an-synchronous low } \\
\text { ere terminated at the }\end{array}$ & $\begin{array}{l}\text { cept for TES anc } \\
\text { May-22 June } 20 \\
\text { PE are from obs } \\
\text { vation orbit. }{ }^{{ }^{2} \mathrm{~T}}\end{array}$ & $\begin{array}{l}\text { OSAT (see f } \\
\text { to constrail } \\
\text { ation system } \\
\text { inated in } 20\end{array}$ & $\begin{array}{l}\text { notes } f \text { and } g) .^{b} \\
\text { e spatial distribut } \\
\text { nulation experim } \\
\text { methane retrieva } \\
\text { ments at five acr }\end{array}$ & $\begin{array}{l}\text { nof emissions in Cal } \\
\text { ts (OSSEs). The Call } \\
\text { suality degraded after } \\
\text { s-track points separat }\end{array}$ & $\begin{array}{l}\text { f freedom for } \\
\text { nia. Values ar } \\
\text { aircraft obse } \\
05 .{ }^{\mathrm{f}} \text { TES me } \\
\text { y } 100 \mathrm{~km} \text {, ea }\end{array}$ & $\begin{array}{l}\text { ignal (DOFS) measures the } \\
\text { shown only for satellite inst! } \\
\text { ations have a DOFS of } 12.2 \text {. } \\
\text { urements are limited to the } \\
\text { 1 with a ground footprint dia }\end{array}$ & $\begin{array}{l}\text { ability of the satellite observation } \\
\text { nents used in this work. Results for } \\
\text { e text for details. }{ }^{d} \text { From polar } \\
\text { it tracks. Regular global surveys } \\
\text { ter of } 10 \mathrm{~km} .{ }^{\mathrm{h}} \text { Continental }\end{array}$ \\
\hline
\end{tabular}

is $10 \mathrm{~min}$. In our previous inverse analysis of SCIAMACHY observations for North America (Wecht et al., 2014), we used a larger nested domain $\left(10-70^{\circ} \mathrm{N}, 40-140^{\circ} \mathrm{W}\right)$. Simulations using the two domains show negligible differences over California. The trimmed domain used here makes it computationally feasible to construct the Jacobian matrix $\mathbf{K}$ and from there to obtain the analytical solution Eqs. (2) and (3) with full characterization of error statistics, unlike the numerical solution relying on the GEOS-Chem adjoint as implemented by Wecht et al. (2014). Boundary conditions are treated here by correcting the free-tropospheric background to match the CalNex aircraft observations as described in Sect. 3.

The main sink for atmospheric methane is oxidation by $\mathrm{OH}$ in the troposphere, and this is computed using a 3$\mathrm{D}$ archive of monthly average $\mathrm{OH}$ concentrations from a GEOS-Chem simulation of tropospheric chemistry (Park et al., 2004). Additional minor sinks in GEOS-Chem include soil absorption (Fung et al., 1991) and stratospheric oxidation computed with archived loss frequencies from the NASA Global Modeling Initiative (GMI) Combo CTM (Considine et al., 2008; Allen et al., 2010). Tropospheric loss of methane is inconsequential here since ventilation from the western US window domain is fast in comparison. Stratospheric loss provides a realistic stratospheric profile of methane, and Wecht et al. (2012) pointed out that this is important for the inversion of satellite observations.

\subsection{A priori emissions for the inversion}

A priori anthropogenic emissions in GEOS-Chem are from the EDGAR v4.2 global inventory at $0.1^{\circ} \times 0.1^{\circ}$ resolution for 2008, the most recent year available (EC-JRC/PBL 2009). CARB only reports statewide totals. A gridded in- ventory scaled to match CARB totals is available from the California Greenhouse Gas Emissions Measurement (CalGEM) project, described by Zhao et al. (2009) and Jeong et al. (2012). The EDGAR v4.2 inventory on the scale of the US agrees well with the US Environmental Protection Agency (EPA, 2013) national inventory (Wecht et al., 2014). EDGAR emissions are aseasonal, but we apply seasonality to California rice emissions following McMillan et al. (2007) with emissions in the growing season (June-September) 6 times higher than in the rest of the year. Natural emissions include open fires from GFED-3 with daily resolution (van der Werf et al., 2010; Mu et al., 2010) and wetlands with dependence on local temperature and soil moisture (Kaplan et al., 2002; Pickett-Heaps et al., 2011). They account for only $3 \%$ of total a priori methane emissions in California.

Table 2 shows the statewide emissions in the EDGAR and CARB inventories, with the contributions from different sources. EDGAR emissions are $1.92 \mathrm{Tg} \mathrm{a}^{-1}, 27 \%$ higher than CARB emissions of $1.51 \mathrm{Tg} \mathrm{a}^{-1}$. There are larger discrepancies in contributions from different source types. EDGAR landfills/wastewater and gas/oil emissions are higher than CARB by more than a factor of 2 . EDGAR livestock emissions, on the other hand, are lower than CARB by a factor of 2. The CalNex observations can arbitrate on these discrepancies, as will be discussed in Sect. 3.3.

Figure 1 shows the distribution of EDGARv4.2 emissions across California. Landfill/wastewater and gas/oil emissions closely follow population distribution. Landfill/wastewater includes landfills $(79 \%)$ and wastewater treatment $(21 \%)$ with similar spatial patterns in EDGAR. The gas/oil source is dominated by natural gas emissions (94\%). EDGAR spatially allocates gas/oil emissions using both extraction and distribution data, yet the correlation with population 
Table 2. Methane emissions in California ${ }^{\mathrm{a}}$.

\begin{tabular}{llllll}
\hline & CARB & EDGAR v4.2 $^{\mathrm{b}}$ & Santoni et al. (2014a) $^{\mathrm{c}}$ & This study $^{\mathrm{d}}$ & Other studies $^{\mathrm{e}}$ \\
\hline State Total & 1.51 & 1.92 & $2.37 \pm 0.27$ & $2.86 \pm 0.21$ & \\
Landfills/wastewater $^{\mathrm{f}}$ & 0.39 & 0.82 & $0.42^{\mathrm{g}}$ & 1.05 & \\
Gas/oil & 0.18 & 0.51 & footnote c & 0.64 & \\
Livestock & 0.86 & 0.46 & 1.29 & 0.87 & \\
Rice & 0.027 & 0.033 & 0.069 & 0.08 & $0.078-0.093^{\mathrm{h}}$ \\
Other $^{\mathrm{i}}$ & 0.05 & 0.10 & footnote c & 0.13 & \\
Naturaj & & & & 0.08 & \\
Los Angeles Basin & & 0.54 & $0.28-0.39$ & $0.42 \pm 0.08$ & $0.6 \pm 0.1^{1}$ \\
& & & & $0.31 \pm 0.08^{\mathrm{k}}$ & $0.38 \pm 0.1^{\mathrm{m}}$ \\
& & & & & $0.44 \pm 0.15^{\mathrm{n}}$ \\
& & & & & $0.41 \pm 0.04^{\circ}$ \\
\hline
\end{tabular}

\footnotetext{
${ }^{a}$ Units are $\mathrm{Tg} \mathrm{a}^{-1}$. Estimates from the CARB and EDGAR v4.2 inventories are compared to inversion results from this work and other studies. Values are for 2010 unless otherwise noted. ${ }^{b}$ For 2008, the latest year available. ${ }^{c}$ Lagrangian inversion using CalNex observations and resolving eight source types/regions. They give a total emission estimate of $0.59 \mathrm{Tg} \mathrm{a}^{-1}$ from the sum of wastewater, gas/oil, and other sources without a further source breakdown. ${ }^{\mathrm{d}}$ Inversion at $1 / 2^{\circ} \times 2 / 3^{\circ}$ resolution using CalNex observations unless otherwise indicated; source type attribution is inferred by mapping optimized emissions to the EDGAR source type distributions. ${ }^{\mathrm{e}}$ Estimates constrained by atmospheric observations from surface or aircraft. ${ }^{\mathrm{f}}$ These two sources are combined here because of the similarity of their geographical distributions in EDGAR v4.2. Landfills account for $80 \%$ of this combined source according to both CARB and EDGAR v4.2. ${ }^{\mathrm{g}}$ Landfills only. ${ }^{\mathrm{h}}$ McMillan et al. (2007) and Peischl et al. (2012). ${ }^{\mathrm{i}}$ Including biofuels and other minor sources. ${ }^{\mathrm{j}}$ Including wetlands, termites, and open fires. ${ }^{\mathrm{k}}$ From inversion of GOSAT observations during CalNex. ${ }^{\mathrm{l}}$ Wunch et al. (2009) estimate for 2007-2008. ${ }^{\mathrm{m}}$ Hsu et al. (2010) estimate for 2007-2008. ${ }^{\mathrm{n}}$ Wennberg et al. (2012) estimate for both 2008 and $2010 .{ }^{\circ}$ Peischl et al. (2013).
}
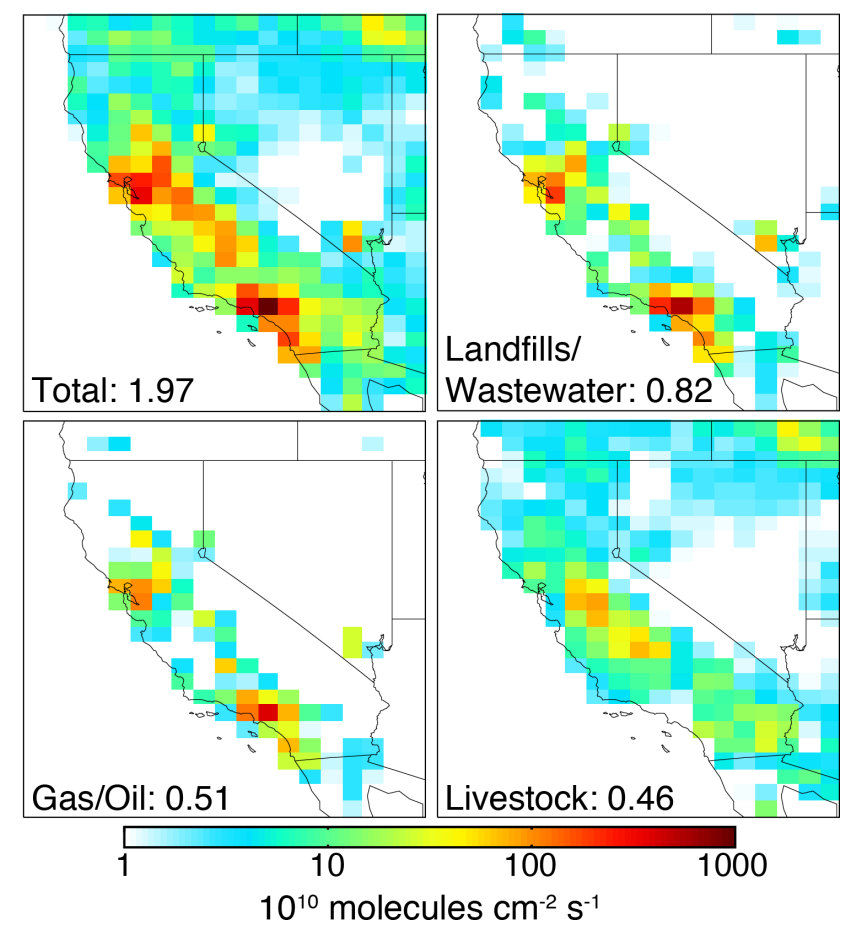

Figure 1. EDGAR v4.2 methane emissions for 2008 used as a priori for our inversion. Panels show total emissions and contributions from the three major source types. California totals in $\mathrm{Tg} \mathrm{a}^{-1}$ are inset. Values are averaged over the $1 / 2^{\circ} \times 2 / 3^{\circ}$ GEOS-Chem grid. suggests that the emissions are mostly from distribution rather than extraction, which is concentrated in the southwestern end of the Central Valley. Livestock emissions are mostly in the Central Valley and include both enteric fermentation and manure management.

\section{Inversion of CalNex observations}

\subsection{Observations and error characterization}

Santoni et al. (2014a) measured methane concentrations aboard the CalNex aircraft from 1 May to 22 June 2010 with a quantum cascade laser spectrometer (QCLS) (Santoni et al., 2014b). They derived methane emissions from these observations with an inversion using the Stochastic TimeInverted Lagrangian Transport (STILT) model. Methane was also measured aboard the CalNex aircraft with a cavity ring-down spectrometer (CRDS) (Peischl et al., 2012), and Santoni et al. (2014a) used these observations to fill gaps in the QCLS record after correcting for bias between the two instruments. They used observations between 2 and $4 \mathrm{~km}$ for each flight to constrain the free-tropospheric background, and the observations below $2 \mathrm{~km}$ to constrain California emissions. We follow the same approach here, correcting the GEOS-Chem concentrations for the observed free-tropospheric background on individual days. Santoni et al. (2014a) show that prevailing winds during the CalNex period are from the west and northwest, over the $\mathrm{Pa}$ cific. The free-tropospheric background correction therefore 
effectively accounts for boundary conditions. Data selection criteria are described by Santoni et al. (2014a).

Figure 2 (top left) shows the mean observed methane concentrations below $2 \mathrm{~km}$ from the 11 daytime CalNex flights used by Santoni et al. (2014a) in their inversion. The means were computed by even pressure-weighted sampling of the 0-2 km column, as described below. Values are highest over the Central Valley and the Los Angeles Basin. For purpose of our inversion we average the CalNex data horizontally, vertically, and temporally over the GEOS-Chem grid. The resulting observation vector $\boldsymbol{y}$ has 1993 elements. We use it to optimize emissions (state vector $\boldsymbol{x}$ ) for the 157 $1 / 2^{\circ} \times 2 / 3^{\circ}$ model grid squares that comprise California. The top right panel of Fig. 2 shows the GEOS-Chem simulation with a priori EDGAR emissions and after correcting for the free-tropospheric background. There is a general underestimate and discrepancies in patterns that point to errors in the EDGAR emissions.

We use the residual error method of Heald et al. (2004) to estimate the observational error variances (diagonal elements of $\mathbf{S}_{\mathrm{O}}$ ). This involves partitioning of the observation vector into coherent subsets within which the error statistics can be assumed homogeneous. The subsets are defined here by altitude and geographical region: Central Valley, Los Angeles Basin, San Francisco Bay Area, rest of California, and Pacific Ocean. For each subset we assume that the mean difference between observations and the model with a priori sources is caused by error on the a priori sources. The residual standard deviation (RSD) is then assumed to represent the standard deviation of the observational error. RSD is largest (50$70 \mathrm{ppb}$ ) in the lowest $1 \mathrm{~km}$ over the Central Valley and the Los Angeles Basin, reflecting small-scale transport and spatial variability in emissions not resolved by the model. RSD below $1 \mathrm{~km}$ in other regions is typically $20-40 \mathrm{ppb}$. RSD in all regions decreases with altitude to $15-20 \mathrm{ppb}$ at $2 \mathrm{~km}$. For each element of $\boldsymbol{y}$ in the subset we populate the diagonal of $\mathbf{S}_{\mathrm{O}}$ with the observational error variance, $\mathrm{RSD}^{2}$. Variograms show no significant temporal or horizontal error correlations between observations on the GEOS-Chem grid. We therefore take $\mathbf{S}_{\mathrm{O}}$ to be diagonal.

The a priori error covariance matrix, $\mathbf{S}_{\mathrm{A}}$, is constructed by assuming a uniform $75 \%$ uncertainty on a priori emissions from every grid square. This magnitude of uncertainty is consistent with the discrepancies between CARB and EDGAR and with the results of Santoni et al. (2014a). We assume no error correlations so that $\mathbf{S}_{\mathrm{A}}$ is diagonal. Sensitivity of the inversion results to specification of $\mathbf{S}_{\mathrm{A}}$ is examined in Sect. 3.3.

Care is required to account for model errors in model transport. Previous comparisons of GEOS-Chem results with ozone and aerosol surface observations in California do not show any evident bias associated with transport (Wang et al., 2009; Zhang et al., 2012). A particular issue in the Central Valley and Los Angeles Basin is the restricted ventilation due to shallow planetary boundary layer (PBL) heights combined with topographical blocking. High-spectral-resolution
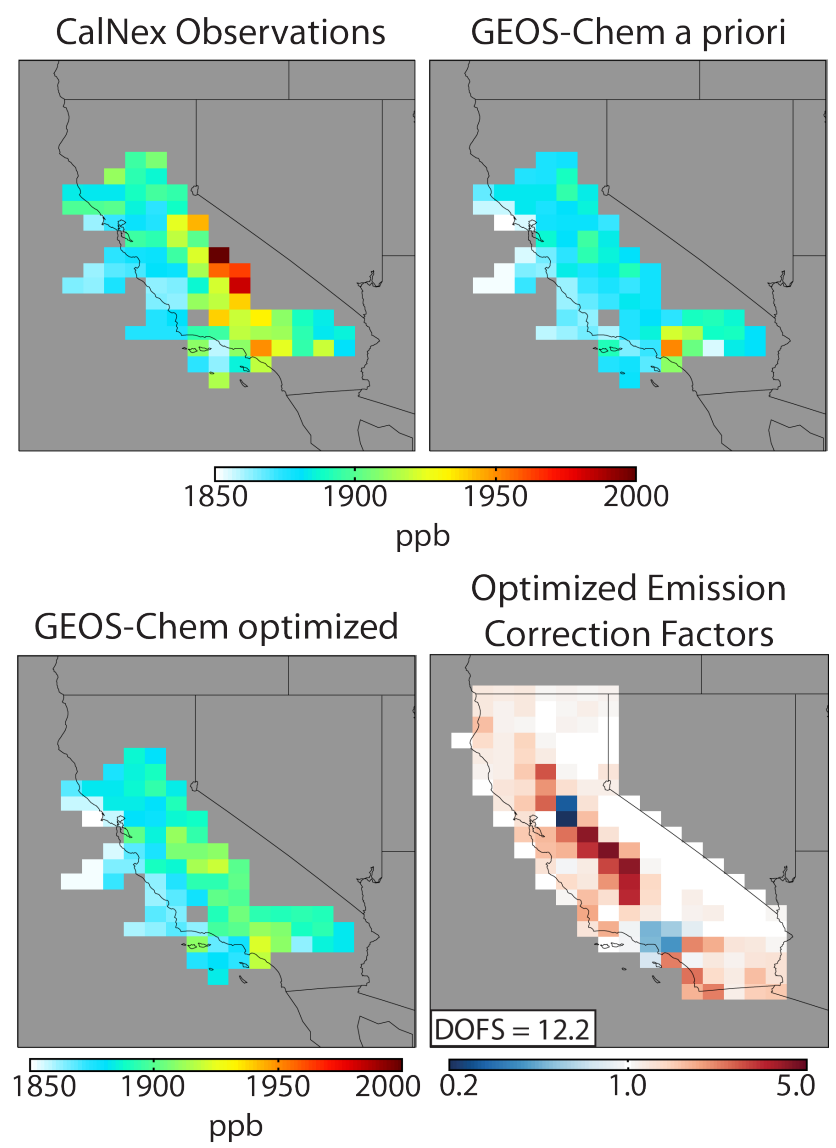

Figure 2. Mean methane concentrations below $2 \mathrm{~km}$ altitude during CalNex (May-June 2010). The top left panel shows aircraft observations averaged on the $1 / 2^{\circ} \times 2 / 3^{\circ}$ GEOS-Chem grid. The top right panel shows the GEOS-Chem simulation using EDGAR v4.2 a priori emissions (Fig. 1). The bottom left panel shows the GEOS-Chem simulation using optimized emissions from inversion of the CalNex observations. All model concentrations reflect an adjusted free-tropospheric background (see text). All concentrations are vertical averages computed by even pressure-weighted sampling throughout the $0-2 \mathrm{~km}$ column (see text). The bottom right panel shows the optimized correction factors to the EDGAR v4.2 emissions from inversion of the CalNex observations are shown at top right. DOFS from the inversion is inset. Gray grid squares are excluded from the optimization.

lidar (HSRL) aircraft observations during CalNex indicated mean midday PBL heights of $1.0 \mathrm{~km}$ in the Central Valley and the Los Angeles Basin (Fast et al., 2012). The PBL heights in the GEOS-5 meteorological data used to enforce vertical mixing in GEOS-Chem are biased high by $0.3 \mathrm{~km}$ in both regions. This would be of no consequence if the $0-2$ $\mathrm{km}$ column were evenly sampled in pressure by the observations because model underestimates in the true PBL would be compensated for by overestimates just above. However, $79 \%$ of the observations in the $0-2 \mathrm{~km}$ column are in fact below $1 \mathrm{~km}$ altitude and a PBL bias would cause a model underestimate unrelated to emissions. To address this we weigh 


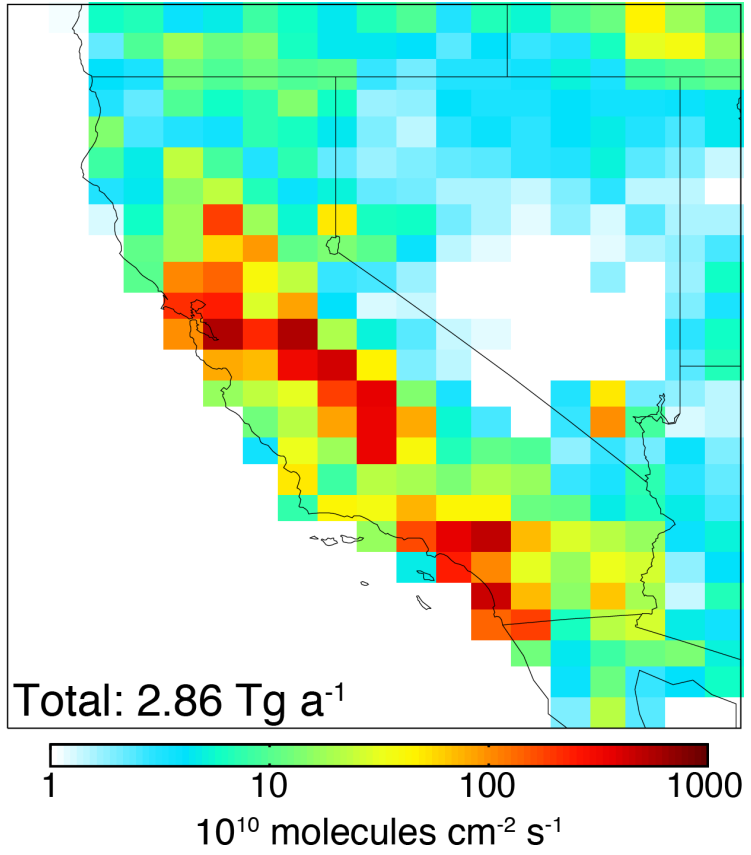

Figure 3. Optimized methane emissions from our inversion using CalNex observations. Total California emissions are inset. See Table 2 for source type attribution.

the individual CalNex observations in the inversion to enforce even pressure-weighted sampling of the $0-2 \mathrm{~km}$ column. This even sampling mitigates the impact of vertical transport errors, such as bias PBL height, that lead to systematically biased model concentrations near the surface.

\subsection{Inversion results}

Figure 2 (bottom left) shows model concentrations using the optimized emissions, averaged vertically to ensure even pressure-weighted sampling of the $0-2 \mathrm{~km}$ columns described above. Figure 2 (bottom right) shows optimized correction factors to the EDGAR v4.2 a priori emissions from the inversion, and Fig. 3 shows the optimized emissions. We report optimized emissions in units of $\mathrm{Tg} \mathrm{a}^{-1}$, assuming no seasonality in anthropogenic sources (Jeong et al., 2012) except for rice cultivation, as described above. Oil and gas production in particular have no significant seasonality (EIA, 2014a); natural gas distribution has a seasonal amplitude of $\pm 25 \%$ (EIA, 2014b) but is a small contributor to statewide methane emissions (CARB, 2011).

The optimized state total emission in California is $2.86 \pm 0.21 \mathrm{Tg} \mathrm{a}^{-1}$, compared with $1.92 \mathrm{Tg} \mathrm{a}^{-1}$ for EDGAR and $1.51 \mathrm{Tg} \mathrm{a}^{-1}$ for CARB. The uncertainty on the optimized estimate represents one standard deviation and is provided by the error covariance matrix $\hat{\mathbf{S}}$ computed from Eq. (3). Emissions increase relative to EDGAR v4.2 primarily over the Central Valley by up to a factor of 4.5. The increase largely follows the pattern of livestock emissions. Emissions decrease over the Los Angeles Basin and the area around Sacramento. Source type allocation is further discussed in Sect. 3.3.

Table 2 compares the statewide emissions calculated here and by Santoni et al. (2014a). Our state total is larger than their $2.37 \pm 0.27 \mathrm{Tg} \mathrm{a}^{-1}$, but this appears to reflect their use of a lower a priori inventory. When they use the EDGAR v4.2 inventory as a priori in a sensitivity inversion, they obtain an optimized emission of $2.8 \mathrm{Tg} \mathrm{a}^{-1}$, consistent with ours. We conducted sensitivity inversions assuming 50 and $100 \%$ uncertainties in the EDGAR v4.2 a priori emissions for individual grid squares (instead of $75 \%$ in the standard inversion) and found optimized statewide emissions of 2.59 and $3.10 \mathrm{Tg} \mathrm{a}^{-1}$, respectively. This illustrates the sensitivity of the optimization to the choice of a priori, although the result that the a priori is too low is robust. Further discussion of the sensitivity of the inverse solution to the a priori is included below.

A number of previous studies have used atmospheric observations to estimate methane emissions in the Los Angeles Basin and find values in the range $0.38-0.6 \mathrm{Tg} \mathrm{a}^{-1}$ (Table 2). Santoni et al. (2014a) estimate a range of 0.29$0.38 \mathrm{Tg} \mathrm{a}^{-1}$. Our inversion yields an optimized estimate of $0.42 \pm 0.08 \mathrm{Tg} \mathrm{a}^{-1}$ for the Los Angeles Basin, in the range of these previous studies.

The extent to which the inversion can constrain the spatial distribution of emissions in California can be measured by the degrees of freedom for signal (DOFS), calculated as the trace of the averaging kernel matrix A (Rodgers, 2000). DOFS is a measure of the number of independent elements in the retrieved emission field. Equation (4) shows that $\mathbf{A}$ reflects the degree to which uncertainty has been reduced in the vector of optimized emissions. Higher DOFS, or larger values on the diagonal of $\mathbf{A}$, mean that more information is available to constrain the spatial distribution of emissions. In an ideal inversion where all $n$ state vector elements (emissions in individual grid squares) are fully constrained by the observations, A would be the identity matrix and we would have $\mathrm{DOFS}=n$.

Figure 4 (top left) shows a map of the diagonal elements of $\mathbf{A}$ in each grid square for the CalNex inversion. Values represent the degrees of freedom associated with each grid square, i.e., the ability of the observations to constrain emissions in that grid square $(1=$ fully, $0=$ not at all), or in other words the relative contributions of the observations and the a priori in constraining the inverse solution. Evaluating the spatial distribution of DOFS therefore allows us to understand the influence of the a priori on our inversion results. Aggregating state vector elements in the inversion would decrease the influence of the a priori but at the cost of increased aggregation error (Wecht et al., 2014).

We find DOFS approaching 1 in the Los Angeles Basin and the San Francisco Bay area, indicating that the observations provide tight constraints on emissions from those regions. We confirm this by examining results from 
sensitivity inversions assuming 50, 75 (standard inversion), and $100 \%$ uncertainties in a priori emissions. In these cases, Los Angeles Basin emissions are 0.42, 0.42, and $0.43 \mathrm{Tg} \mathrm{a}^{-1}$, respectively, and San Francisco Bay area emissions are 0.43, 0.39 , and $0.37 \mathrm{Tg} \mathrm{a}^{-1}$, respectively.

DOFS in the Central Valley is typically $0.2-0.8$, indicating that the inverse solution reflects information from both the observations and the a priori. Although CalNex provides many observations in the Central Valley, those observations are associated with large RSD, likely due to fine-scale emissions and/or transport unresolved by the $1 / 2^{\circ} \times 2 / 3^{\circ}$ model resolution. In this case, the goal of the inversion is not to eliminate the a priori influence. Rather, the a priori tempers the inversion, preventing it from completely eliminating model-observation residuals that may be affected by model errors. This explains why the optimized methane concentrations in Fig. 2 (bottom left) do not match the observations in the Central Valley. Central Valley emissions from the three sensitivity inversions are 1.02, 1.23, and $1.38 \mathrm{Tg} \mathrm{a}^{-1}$, respectively.

Low DOFS is associated with areas that were either not adequately covered by the CalNex aircraft (Fig. 2) or have low a priori emissions (Figure 1) and thus have little influence on the inversion. Emissions from these grid cells are sensitive to the a priori specification. Overall our inversion has a total DOFS for California of 12.2, indicating that we can constrain 12 independent pieces of information.

\subsection{Attribution to source types}

Our inversion optimizes methane emissions on a geographical grid without a priori consideration of source type. This can be contrasted to the Santoni et al. (2014a) inversion, which optimized emissions by source type assuming that the a priori pattern for each source type was correct. Ultimately, our spatial correction factors need to be related to source types in order to guide the improvement of inventories. This can be done by mapping the results onto the a priori source patterns of Fig. 1, with the caveat that the patterns may not be correct.

We conducted the mapping of our optimized emissions to source types by applying the optimized emission correction factors for each grid square (bottom right panel of Fig. 2) to the relative contributions from each major source type in that grid square, as given by the EDGAR v4.2 inventory and plotted in Fig. 1. This method assumes that EDGAR correctly identifies the relative contributions of each source type to the total emissions in a given grid square. It does not assume that the statewide patterns are correct - in fact these are corrected by the inversion. Results in Table 2 show that livestock emissions increase statewide by $92 \%$ relative to EDGAR, landfill/wastewater by $28 \%$, and gas/oil by $26 \%$.

We pointed out above the large discrepancies between CARB and EDGAR for different source types (Table 2). Our livestock estimate is much higher than EDGAR but agrees
Inversion Degrees of Freedom per Grid Square

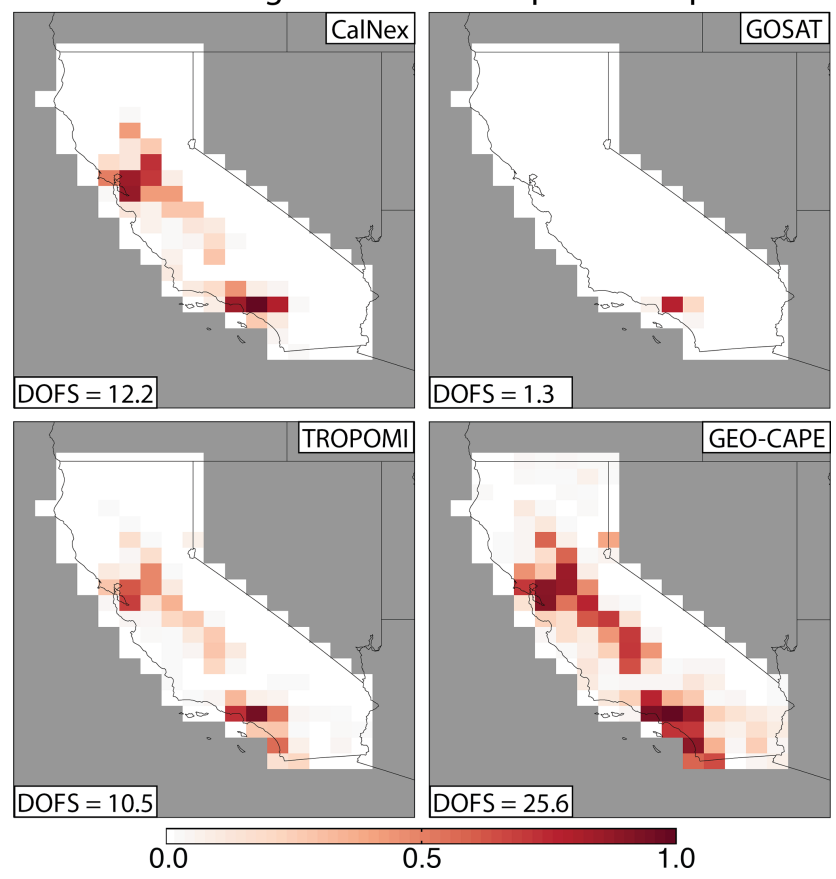

Figure 4. Degrees of freedom in each grid square from our inversions using CalNex (top left) and GOSAT (top right) observations and from our observation system simulation experiments (OSSEs) using TROPOMI (bottom left) and GEO-CAPE (bottom right) synthetic observations. Values are the diagonal elements of the averaging kernel matrix for the inversion and represent the ability of the observations to constrain local emissions (see text). The sum of these degrees of freedom (trace of the average kernel matrix) represents the degrees of freedom for signal (DOFS) of the inversions, inset. Gray grid squares are excluded from the optimization.

with CARB, in contrast to Santoni et al. (2014a), who concluded that livestock emissions in CARB are $50 \%$ too low. On the other hand, our emissions from landfills/wastewater and gas/oil are higher than CARB by factors of 2.7 and 3.6, respectively, and are in closer agreement with EDGAR. Rice paddies in the Sacramento Valley were sampled by two flights on 11 May and 14 June that straddle the onset of rice emissions. Rice emissions, although small, are underestimated by a factor of 2-3 in the CARB and EDGAR inventories, consistent with the previous findings of McMillan et al. (2007) and Peischl et al. (2012).

\section{Utility of current satellites (GOSAT, TES) for constraining California emissions}

Satellite observations of atmospheric methane from GOSAT and TES were operational during CalNex and we examine their combined value for constraining emissions from California over that period. GOSAT is in a Sun-synchronous polar orbit with an Equator overpass local time of $\sim 13: 00$. 
It retrieves methane from nadir SWIR spectra near $1.6 \mu \mathrm{m}$. Measurements consist of five across-track points separated by $\sim 100 \mathrm{~km}$, with footprint diameters of $10.5 \mathrm{~km}$. Observations are limited to daytime and land. We use the University of Leicester GOSAT Proxy XCH4 v3.2 data described by Parker et al. (2011) (available from http://www.leos.le.ac. $\mathrm{uk} / \mathrm{GHG} / \mathrm{data} /$ ) to populate our observation vector $\boldsymbol{y}$. These data are for methane column mixing ratios $X_{\mathrm{CH}_{4}}[v / v]$ retrieved by the $\mathrm{CO}_{2}$ proxy method:

$X_{\mathrm{CH}_{4}}=\frac{X_{\mathrm{CO}_{2}}}{\Omega_{\mathrm{CO}_{2}}}\left(\Omega_{\mathrm{A}}+\boldsymbol{a}^{T}\left(\boldsymbol{\omega}-\boldsymbol{\omega}_{\mathrm{A}}\right)\right)$,

where $\omega$ is the true vertical profile of methane consisting of 20 partial columns, $\omega_{\mathrm{A}}$ is the a priori profile provided by the TM3 chemical transport model, $\Omega_{\mathrm{A}}$ is the corresponding a priori column concentration of methane [molecules $\mathrm{cm}^{-2}$ ], $\boldsymbol{a}$ is an averaging kernel vector that describes the sensitivity as a function of altitude, $\Omega_{\mathrm{CO}_{2}}$ is the measured vertical column concentration of $\mathrm{CO}_{2}$, and $X_{\mathrm{CO}_{2}}$ is a modeled column mixing ratio of $\mathrm{CO}_{2}$. The sensitivity characterized by $\boldsymbol{a}$ is nearly uniform in the troposphere and decreases with altitude in the stratosphere. The normalization by $\mathrm{CO}_{2}$ corrects for aerosol and partial cloud effects as described by Frankenberg et al. (2006).

TES is in a Sun-synchronous polar orbit with an Equator overpass local time of $\sim 13: 45$. It retrieves methane from nadir TIR spectra at 7.58-8.55 $\mu \mathrm{m}$. It makes nadir observations with a pixel resolution of $5.3 \times 8.3 \mathrm{~km}^{2}$ every $182 \mathrm{~km}$ along the orbit track. Successive orbit tracks are separated by about $22^{\circ}$ longitude. We use the most recent V005 Lite product (Worden et al., 2012; http://tes.jpl.nasa.gov/data/). Vertical methane profiles are retrieved as

$\ln =\ln \hat{z}_{\mathrm{A}}+\mathbf{A}^{\prime}\left(\ln z-\ln z_{\mathrm{A}}\right)$,

where $\hat{z}$ is the retrieved vertical profile vector consisting of mixing ratios on a fixed pressure grid, $\mathbf{A}^{\prime}$ is the averaging kernel matrix that represents the sensitivity of the retrieved profile to the true profile $z$, and $z_{\mathrm{A}}$ is an a priori profile from the MOZART CTM. TES is mostly sensitive to the middle and upper troposphere and insensitive to the boundary layer. It is therefore not used as part of the observation vector, $\boldsymbol{y}$. Instead, we use it to characterize the free-tropospheric background against which the boundary layer enhancements detected by GOSAT can be measured. This correction is necessary to ensure that a free-tropospheric model bias does not impact the inverse solution.

We use GOSAT and TES observations for the CalNex period, 1 May to 22 June 2010 , and for the domain $\left(32-42^{\circ} \mathrm{N}\right.$, $125-114^{\circ} \mathrm{W}$ ), as shown in Fig. 5. There are 257 GOSAT and 133 TES observations on the GEOS-Chem grid. We subtract biases from GOSAT ( $-7.5 \mathrm{ppb})$ and TES (28 ppb) based on validations of Parker et al. (2011) and Wecht et al. (2012), respectively. We subtract a mean bias of $1.5 \mathrm{ppb}$ from GEOSChem based on comparison with TES as measure of the tropospheric background.

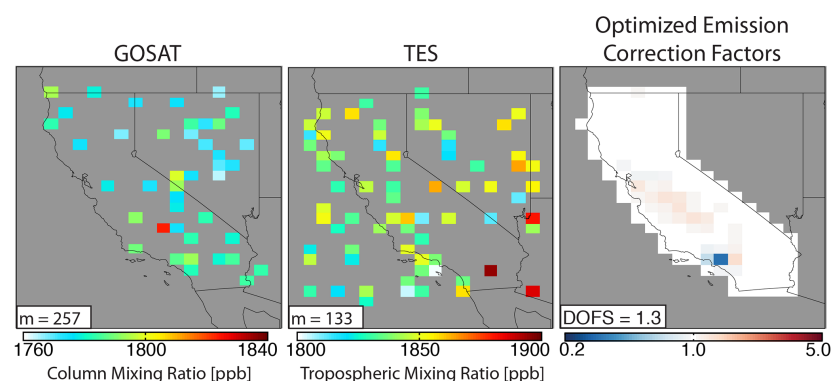

Figure 5. Mean methane mixing ratios measured by GOSAT (top left) and TES (top right) for the CalNex period of 1 May22 June 2010, a priori model concentrations (bottom left) at the times and locations of GOSAT, and optimized correction factors (bottom right) to the a priori EDGAR v4.2 methane emissions from the GOSAT inversion. Observations are plotted on the GEOS-Chem grid. The total number $(m)$ of observations is inset. The TES data are vertical averages of tropospheric levels, while the GOSAT data are average column mixing ratios including the stratosphere, which explains the lower values. Model concentrations are sampled at the times and locations of GOSAT observations and have the GOSAT observation operator applied. DOFS from the GOSAT inversion is inset in the right panel. Gray grid squares in the right panel are excluded from the optimization.

Figure 5 (bottom right) shows the optimized correction factors to the a priori EDGAR v4.2 emissions for an inversion using the GOSAT observations. Observational errors for the inversion are determined using the residual error method described above and indicate RSD values in the range $10-12 \mathrm{ppb}$. The inversion has a DOFS of 1.3, compared to 12.2 for the inversion using the CalNex observations. The correction factors have a pattern similar to those from the CalNex inversion, showing that the constraints from GOSAT on methane emissions are qualitatively consistent with CalNex. However, Central Valley correction factors are driven by just three observations located at the southern end of the Valley, apparent in Fig. 5. Overall, correction factors are much weaker than in the CalNex inversion, reflecting the low DOFS. A map of the degrees of freedom associated with each grid square is shown in Fig. 4 (top, right). In total, 1.1 of the DOFS from GOSAT is for the Los Angeles Basin, and the optimization of emissions there should be quantitative: we find $0.31 \pm 0.08 \mathrm{Tg} \mathrm{a}^{-1}$, at the lower end of values in Table 2. Outside of the Los Angeles Basin the DOFS sum to just 0.2 .

Satellites provide continuous observations not limited by the duration of an aircraft campaign. Using GOSAT data for a full year, rather than the 53 days used here, would decrease the observational error by a factor 2.6 following the central limit theorem if the error can be assumed random, if the distribution of observations remains constant, and if the seasonality in methane emission ignored (or a priori constrained). The resulting DOFS would be 3.3. Using the full 6-year GOSAT record to date (2009-2014) would 
increase the DOFS to 8.1 following the same assumptions and further assuming negligible trend in emissions over the 6 years. The multiyear GOSAT data can usefully constrain emissions over the US on a $\sim 100 \mathrm{~km}$ scale (Turner et al., 2013) but still fall short at the finer scale used here for California.

\section{Potential of future satellites (TROPOMI, geostationary)}

The TROPOMI satellite instrument (2015 launch) will measure atmospheric methane with far greater coverage than either GOSAT or TES (Table 1). There are in addition several proposals to measure methane from geostationary orbit and the GEO-CAPE instrument described by Fishman et al. (2012) presents such a possibility. We conducted OSSEs to evaluate the potential of these future satellite instruments for constraining California methane emissions. For this purpose, we take the CalNex optimized emissions in Fig. 3 as the "true" emissions to be retrieved by the inversion, and use these emissions in GEOS-Chem to generate a "true" atmosphere (sampled on CalNex flight tracks in bottom left panel of Fig. 2). We sample this "true" atmosphere with the observation frequency of TROPOMI and GEO-CAPE, apply the corresponding averaging kernels for the instruments, and add random Gaussian noise of the expected magnitude. Instrument specifications are in Table 1 . We then conduct an inversion of these synthetic observations exactly as described above, using the a priori emissions described in Sect. 2.2 and shown in Fig. 1, and diagnose the potential value of the satellite instruments by their ability to constrain a priori sources as measured by the DOFS. A caveat is that the OSSE uses the same forward model to generate synthetic observations and to invert these observations, and this may lead to overoptimistic inversion results.

We perform OSSEs for the CalNex period of 1 May22 June 2010 and using synthetic observations for the land domain $\left(32-42^{\circ} \mathrm{N}, 125-114^{\circ} \mathrm{W}\right)$ in the same way as for GOSAT. TROPOMI observations provide complete coverage daily and GEO-CAPE hourly. Both TROPOMI and GEOCAPE are SWIR instruments and we use a single averaging kernel from GOSAT to generate synthetic observations for both; this is of little consequence as the averaging kernel for SWIR observations is near unity in the troposphere in any case. We randomly remove $80 \%$ of synthetic observations to simulate the effect of cloud cover. In reality, cloud-free observations will not be random, and the different pixel sizes of TROPOMI and GEO-CAPE observations will lead to different fractions of cloud-free observations. Each element of the observation vector $\boldsymbol{y}$ represents the average methane column mixing ratio observed over a GEOS-Chem grid square at a given time, including measurement error variance as defined by the precisions from Table 1 . When multiple synthetic observations exist in the same $1 / 2^{\circ} \times 2 / 3^{\circ}$ GEOS-Chem grid square, we assume Gaussian uncorrelated errors and average them into one single observation with square root decrease of the measurement error variance following the central limit theorem.

Observational error for the OSSE is estimated as the sum of measurement and model error, since the measurements are dense enough that representation error can be neglected. We specify the model error standard deviation to be $12 \mathrm{ppb}$, a conservative estimate based on the observational error for GOSAT. Measurement and model error variances are added in quadrature to populate the diagonal of $\mathbf{S}_{\mathrm{O}}$ and off-diagonal terms are ignored. Model error dominates measurement error because of the averaging of the measurements over GEOSChem grid squares described above. The a priori error covariance matrix is populated in the same way as above. We assume no background bias in the model or observations as this could be corrected through other observations such as a TIR instrument (e.g., TES for GOSAT) or by iterative adjustment of emissions and boundary conditions in the inversion (Wecht et al., 2014). Again, however, this may lead to overoptimistic results.

Figure 4 (bottom) summarizes the OSSE results. The TROPOMI inversion has 10.5 DOFS (Fig. 4, bottom, left), comparable to the CalNex inversion (12.2 DOFS), and it accurately captures the spatial pattern of a priori emission errors. Optimized statewide emissions are $2.60 \mathrm{Tg} \mathrm{a}^{-1}$, compared with $2.86 \mathrm{Tg} \mathrm{a}^{-1}$ from the "true" emissions. We conclude that TROPOMI may perform just as well as a dedicated aircraft campaign (CalNex), and is thus highly promising for constraining emissions at the state level. The GEOCAPE inversion has 26.5 DOFS (Fig. 4, bottom right), much higher than CalNex and TROPOMI, reflecting the greater density of observations. Optimized statewide emissions are $2.79 \mathrm{Tg} \mathrm{a}^{-1}$, close to the "true" emissions of $2.86 \mathrm{Tg} \mathrm{a}^{-1}$. This reveals the considerable potential of geostationary observations for monitoring methane emissions on fine scales.

\section{Conclusions}

We applied an inverse modeling system based on the GEOSChem Eulerian chemical transport model (CTM) to optimize methane emissions from Califonia with $1 / 2^{\circ} \times 2 / 3^{\circ}$ horizontal resolution using observations from the May-June 2010 CalNex aircraft campaign. The system is designed to optimize emissions on the continental scale using satellite observations (Wecht et al., 2014), and here we evaluated its potential to constrain the spatial distribution of emissions at the state level. We compared the constraints achievable with the CalNex aircraft observations to those achievable from current (GOSAT, TES) and future (TROPOMI, geostationary) satellite observations of methane. We also compared the Eulerian GEOS-Chem inversion of CalNex observations to a Lagrangian (STILT) inversion of methane emissions using exactly the same observations (Santoni et al., 2014a), 
thus providing a perspective on the use of different inversion methodologies. Because the inversion was conducted over a limited spatial domain, we could obtain analytical solutions with full error characterization to compare the different observing systems.

Our inversion of CalNex observations yields a best estimate of $2.86 \pm 0.21 \mathrm{Tg} \mathrm{a}^{-1}$ for total California emissions, compared to $1.92 \mathrm{Tg} \mathrm{a}^{-1}$ in the EDGAR v4.2 inventory used as a priori for the inversion, $1.51 \mathrm{Tg} \mathrm{a}^{-1}$ in the California Air Resources Board (CARB) inventory used as basis to regulate greenhouse gas emissions in California, and $2.37 \pm 0.27 \mathrm{Tg} \mathrm{a}^{-1}$ in the Santoni et al. (2014a) inversion. Our results are consistent with Santoni et al. (2014a) considering that they used a lower a priori emission estimate for their inversion. An important distinction between the two inversions is that we optimize emissions geographically in 157 grid squares whereas they optimize emissions for 8 source types. Error statistics on our inversion indicates that it provides 12 independent pieces of information (measured by degrees of freedom for signal, DOFS). We have particularly strong constraints on emissions in the Los Angeles Basin, where our emission estimate $\left(0.42 \pm 0.08 \mathrm{Tg} \mathrm{a}^{-1}\right)$ is consistent with previous studies.

The CARB and EDGAR v4.2 emission inventories show factor-of-2 differences between each other in their state total estimates of emissions from livestock, landfills/wastewater, and gas/oil. Our results provide guidance for resolving these discrepancies. Mapping our optimized estimate of the spatial distribution of California methane emissions onto individual source types indicates a state total livestock emission of $0.87 \mathrm{Tg} \mathrm{a}^{-1}$, in close agreement with CARB but much higher than EDGAR and lower than the $1.29 \mathrm{Tg} \mathrm{a}^{-1}$ estimate of Santoni et al. (2014a). On the other hand, our best estimate of emissions from landfills/wastewater $\left(1.05 \mathrm{Tg} \mathrm{a}^{-1}\right)$ and gas/oil $\left(0.64 \mathrm{Tg} \mathrm{a}^{-1}\right)$ is $20 \%$ higher than EDGAR but much higher than CARB or Santoni et al. (2014a). Our results suggest that the CARB inventory should correct its landfills/wastewater and gas/oil emission estimates by upward correction to the EDGAR v4.2 values.

We find that current satellite observations of methane from GOSAT and TES are too sparse to quantitatively constrain California emissions. TES is only useful for constraining the free-tropospheric background. GOSAT provides quantitative constraints on emissions in the Los Angeles Basin $\left(0.31 \pm 0.08 \mathrm{Tg} \mathrm{a}^{-1}\right)$ but not elsewhere. However, the qualitative corrections to a priori emissions from the GOSAT observations across the state are consistent with those from the CalNex observations. They consistently point to a large underestimate of livestock emissions in the EDGAR v4.2 inventory. In the absence of a dedicated aircraft study such as CalNex, GOSAT can be useful as a qualitative indicator of biases in methane emission inventories. Furthermore, assimilating current satellite observations over larger spatiotemporal scales may improve their ability to constrain emissions.
The TROPOMI satellite instrument to be launched in 2015 has considerable potential for improving our capability to monitor methane emissions from space. TROPOMI will provide global daily coverage of methane columns with $7 \times 7 \mathrm{~km}^{2}$ nadir resolution. We find in an observation system simulation experiment (OSSE) that the observing power of TROPOMI for constraining methane emissions in California will be comparable to that of the CalNex aircraft campaign. Geostationary observations of methane proposed for the coming decade have even more potential for constraining methane emissions. These satellite measurements will provide monitoring, reporting, and verification (MRV) for the development of methane emission control strategies in the context of climate policy. This will be particularly important in a world of rapidly changing methane emissions from natural gas exploitation, hydrofracking, and agricultural management practices.

Acknowledgements. This work was supported by the NASA Carbon Monitoring System (CMS), the NASA Atmospheric Composition Modeling and Analysis Program (ACMAP), and by a NASA Earth System Science Fellowship to K. J. Wecht. The University of Leicester GOSAT retrieval was supported by the UK National Centre for Earth Observation and the European Space Agency Climate Change Initiative.

Edited by: M. Heimann

\section{References}

Allen, D., Pickering, K., Duncan, B., and Damon, M.: Impact of lightning NO emissions on North American photochemistry as determined using the Global Modeling Initiative (GMI) model, J. Geophys. Res., 115, D22301, doi:10.1029/2010JD014062, 2010.

Butz, A., Galli, A., Hasekamp, O., Landgraf, J., Tol, P., and Aben, I.: TROPOMI aboard Precursor Sentinel-5 Precursor: Prospective performance of $\mathrm{CH}_{4}$ retrievals for aerosol and cirrus loaded atmospheres, Remote Sens. Environ., 120, 267-276, doi:10.1016/j.rse.2011.05.030, 2012.

California Air Resources Board, California Greenhouse Gas Emission Inventory (CARB): 2000-2009, http://www.arb.ca.gov/cc/ inventory/pubs/reports/ghg_inventory_00-09_report.pdf (last access: 4 August 2014), 2011.

California Air Resources Board, Climate Change Scoping Plan First Update (CARB): Discussion Draft for Public Review and Comment, http://www.arb.ca.gov/cc/scopingplan/2013_update/ discussion_draft.pdf (last access: 4 August 2014), 2013.

National Research Council (NRC), Verifying Greenhouse Gas Emissions: Methods to Support International Climate Agreements, Natil. Acad. Press, Washington DC, 2010.

Considine, D. B., Logan, J. A., and Olsen, M. A.: Evaluation of near-tropopause ozone distributions in the Global Modeling Initiative combined stratosphere/troposphere model with ozonesonde data, Atmos. Chem. Phys., 8, 2365-2385, doi:10.5194/acp-8-2365-2008, 2008.

Crevoisier, C., Nobileau, D., Armante, R., Crépeau, L., Machida, T., Sawa, Y., Matsueda, H., Schuck, T., Thonat, T., Pernin, J., Scott, 
N. A., and Chédin, A.: The 2007-2011 evolution of tropical methane in the mid-troposphere as seen from space by MetOpA/IASI, Atmos. Chem. Phys., 13, 4279-4289, doi:10.5194/acp13-4279-2013, 2013.

European Commission, Joint Research Centre (JRC)/Netherlands Environmental Assessment Agency (PBL), EC-JRC/PBL, Emission Database for Global Atmospheric Research (EDGAR), release version 4.0., http://edgar.jrc.ec.europa.eu (last access: 4 August 2014), 2009.

Fast, J. D., Gustafson Jr., W. I., Berg, L. K., Shaw, W. J., Pekour, M., Shrivastava, M., Barnard, J. C., Ferrare, R. A., Hostetler, C. A., Hair, J. A., Erickson, M., Jobson, B. T., Flowers, B., Dubey, M. K., Springston, S., Pierce, R. B., Dolislager, L., Pederson, J., and Zaveri, R. A.: Transport and mixing patterns over Central California during the carbonaceous aerosol and radiative effects study (CARES), Atmos. Chem. Phys., 12, 1759-1783, doi:10.5194/acp-12-1759-2012, 2012.

Fishman, J., Iraci, L. T., Al-Saadi, J., Chance, K., Chavez, F., Chin, M., Coble, P., Davis, C., DiGiacomo, P. M., Edwards, D., Eldering, A., Goes, J., Herman, J., Hu, C., Jacob, D. J., Jordan, C., Kawa, S. R., Key, R., Liu, X., Lohrenz, S., Mannino, A., Natraj, V., Neil, D., Neu, J., Newchurch, M., Pickering, K., Salisbury, J., Sosik, H., Subramaniam, A., Tzortziou, M., Wang, J., and Wang, M.: The United States' next generation of atmospheric composition and coastal ecosystem measurements: NASA's geostationary coastal and air pollution events (GEO-CAPE) mission, B. Am. Meteorol. Soc., 93, 1547-1566, 2012.

Frankenberg, C., Meirink, J. F., Bergamaschi, P., Goede, A. P. H., Heimann, M., Körner, S., Platt, U., van Weele, M., and Wagner, T.: Satellite chartography of atmospheric methane from SCIAMACHY on board ENVISAT: Analysis of the years 2003 and 2004, J. Geophys. Res., 111, D07303, doi:10.1029/2005JD006235, 2006.

Frankenberg, C., Aben, I., Bergamaschi, P., Dlugokencky, E. J., van Hees, R., Houweling, S., van der Meer, P., Snel, R., and Tol, P.: Global column-averaged methane mixing ratios from 2003 to 2009 as derived from SCIAMACHY: Trends and variability, J. Geophys. Res., 116, D02304, doi:10.1029/2010JD014849, 2011.

Fung, I., John, J., Lerner, J., Matthews, E., Prather, M., Steele, L. P., and Fraser, P. J.: Three-dimensional model synthesis of the global methane cycle, J. Geophys. Res., 96, 13033-13065, 1991.

Heald, C., Jacob, D., Jones, D., Palmer, P., Logan, J., Streets, D., Sachse, G., Gille, J., Hoffman, R., and Nehrkorn, T.: Comparative inverse analysis of satellite (MOPITT) and aircraft (TRACE-P) observations to estimate Asian sources of carbon monoxide, J. Geophys. Res.-Atmos., 109, D23306, doi:10.1029/2004JD005185, 2004.

Hsu, Y.-K., VanCuren, T., Park, S., Jakober, C., Herner, J., FitzGibbon, M., Blake, D. R., and Parrish, D. D.: Methane emission inventory verification in southern California, Atmos. Environ., 44, $1-7,2010$.

Jeong, S., Zhao, C., Andrews, A. E., Bianco, L., Wilczak, J. M., and Fischer, M. L.: Seasonal variation of CH4 emissions from central California, J. Geophys. Res., 117, D11306, doi:10.1029/2011JD016896, 2012.

Kaplan, J. O.: Wetlands at the Last Glacial Maximum: Distribution and methane emissions, Geophys. Res. Lett., 29, 1079, doi:10.1029/2001GL013366, 2002.
McMillan, A. M. S., Goulden, M. L., and Tyler S. C.: Stoichiometry of $\mathrm{CH}_{4}$ and $\mathrm{CO}_{2}$ flux in a California rice paddy, J. Geophys. Res., 112, G01008, doi:10.1029/2006JG000198, 2007.

Mu, M., Randerson, J. T., van der Werf, G. R., Giglio, L., Kasibhatla, P., Morton, D., Collatz, G. J., DeFries, R. S., Hyer, E. J., Prins, E. M., Griffith, D. W. T., Wunch, D., Toon, G. C., Sherlock, V., and Wennberg, P. O.: Daily and 3-hourly variability in global fire emissions and consequences for atmospheric model predictions of carbon monoxide, J. Geophys. Res.-Atmos., 116, D24303, doi:10.1029/2011JD016245, 2010.

Park, R. J., Jacob, D. J., Field, B. D., Yantosca, R. M., and Chin, M.: Natural and transboundary pollution influences on sulfate-nitrate-ammonium aerosols in the United States: implications for policy, J. Geophys. Res., 109, D15204, doi:10.1029/2003JD004473, 2004.

Parker, R., Boesch, H., Cogan, A., Fraser, A., Feng, L., Palmer, P. I., Messerschmidt, J., Deutscher, N., Griffith, D. W., Notholt, J., Wennberg, P. O., and Wunch, D.: Methane observations from the Greenhouse Gases Observing SATellite: Comparison to groundbased TCCON data and model calculations, Geophys. Res. Lett., 38, L15807, doi:10.1029/2011GL047871, 2011.

Peischl, J., Ryerson, T. B., Holloway, J. S., Trainer, M., Andrews, A. E., Atlas, E. L., Blake, D. R., Daube, B. C., Dlugokencky, E. J., Fischer, M. L., Goldstein, A. H., Guha, A., Karl, T., Kofler, J., Kosciuch, E., Misztal, P. K., Perring, A. E., Pollack, I. B., Santoni, G. W., Schwarz, J. P., Spackman, J. R., Wofsy, S. C., and Parrish, D. D.: Airborne observations of methane emissions from rice cultivation in the Sacramento Valley of California, J. Geophys. Res., 117, D00V25, doi:10.1029/2012JD017994, 2012.

Peischl, J., Ryerson, T.B., Brioude, J., Aikin, K.C., Andrews, A.E., Atlas, E.L., Blake, D.R., Daube, B.C., de Gouw, J.A., Dlugokencky, E.J., Frost, G.J., Gentner, D.R., Gilman, J.B., Goldstein, A.H., Harley, R.A., Holloway, J.S., Kofler, J., Kuster, W.C., Lang, P.M., Novelli, P.C., Santoni, G.W., Trainer, M., Wofsy, S.C., and Parrish, D.D., Quantifying sources of methane using light alkanes in the Los Angeles basin, California, J. Geophys. Res.-Atmos., 118, 4974-4990, doi:10.1002/jgrd.50413, 2013.

Pickett-Heaps, C. A., Jacob, D. J., Wecht, K. J., Kort, E. A., Wofsy, S. C., Diskin, G. S., Worthy, D. E. J., Kaplan, J. O., Bey, I., and Drevet, J.: Magnitude and seasonality of wetland methane emissions from the Hudson Bay Lowlands (Canada), Atmos. Chem. Phys., 11, 3773-3779, doi:10.5194/acp-11-3773-2011, 2011.

Rodgers, C. D.: Inverse Methods for Atmospheric Sounding, World Scientific Publishing Co. Pte. Ltd, Tokyo, 25-37, 2000.

Santoni, G. W., Xiang, B., Kort, E. A., Daubel, B. C., Andrews, A. E., Sweeney, C., Wecht, K. J., Peischl, J., Ryerson, T. B., Angevine, W. M., Trainer, M., Nehrkorn, T., Eluszkiewicz, J., Jeong, S., Fischer, M. L., Ferrare, R. A., and Wofsy, S. C.: California's methane budget derived from CalNex P-3 Aircraft Observations and a Lagrangian transport model, J. Geophys. Res., submitted, 2014a.

Santoni, G. W., Daube, B. C., Kort, E. A., Jiménez, R., Park, S., Pittman, J. V., Gottlieb, E., Xiang, B., Zahniser, M. S., Nelson, D. D., McManus, J. B., Peischl, J., Ryerson, T. B., Holloway, J. S., Andrews, A. E., Sweeney, C., Hall, B., Hintsa, E. J., Moore, F. L., Elkins, J. W., Hurst, D. F., Stephens, B. B., Bent, J., and Wofsy, S. C.: Evaluation of the airborne quantum cascade laser spectrometer (QCLS) measurements of the carbon and greenhouse gas suite $-\mathrm{CO}_{2}, \mathrm{CH}_{4}, \mathrm{~N}_{2} \mathrm{O}$, and $\mathrm{CO}-$ during the Cal- 
Nex and HIPPO campaigns, Atmos. Meas. Tech., 7, 1509-1526, doi:10.5194/amt-7-1509-2014, 2014b.

Schepers, D., Guerlet, S., Butz, A., Landgraf, J., Frankenberg, C., Hasekamp, O., Blavier, J.-F., Deutscher, N. M., Griffith, D. W. T., Hase, F., Kyro, E., Morino, I., Sherlock, V., Sussmann, R., and Aben, I.: Methane retrievals from Greenhouse Gases Observing Satellite (GOSAT) shortwave infrared measurements: Performance comparison of proxy and physics retrieval algorithms, J. Geophys. Res., 117, D10307, doi:10.1029/2012JD017549, 2012.

Turner, A. J., Jacob, D. J., Wecht, K. J., Sulprizio, M., Payne, V., Santoni, G., Wofsy, S. C., Bowman, K. W., Parker, R., and Boesch, H.: Optimal estimation of North American methane emissions using GOSAT data: A contribution to the NASA Carbon Monitoring System, paper presented at American Geophysical Union Fall 2013 Meeting, American Geophysical Union, San Francisco, CA, 2013.

United States Energy Information Administration (EIA), California Natural Gas Gross Withdrawals, http://www.eia.gov/dnav/ng/ hist/n9010ca2m.htm, last acces: 16 May 2014a.

United States Energy Information Administration (EIA), Natural Gas Delivered to Consumers in California (Including Vehicle Fuel), http://www.eia.gov/dnav/ng/hist/n3060ca2m.htm, last access: 14 May 2014b.

United States Environmental Protection Agency (EPA), Inventory of U.S. Greenhouse Gas Emissions and Sinks: 19902011-Annexes, http://www.epa.gov/climatechange/Downloads/ ghgemissions/US-GHG-Inventory-2013-Main-Text.pdf (last access: 4 August 2014), 2013.

van der Werf, G. R., Randerson, J. T., Giglio, L., Collatz, G. J., Mu, M., Kasibhatla, P. S., Morton, D. C., DeFries, R. S., Jin, Y., and van Leeuwen, T. T.: Global fire emissions and the contribution of deforestation, savanna, forest, agricultural, and peat fires (19972009), Atmos. Chem. Phys., 10, 11707-11735, doi:10.5194/acp10-11707-2010, 2010.

Veefkind, J. P., Aben, I., McMullan, K., Forster, H., de Vries, J., Otter, G., Claas, J., Eskes, H. J., de Haan, J. F., Kleipool, Q., van Weele, M., Hasekamp, O., Hoogeveen, R., Landgraf, J., Snel, R., Tol, P., Ingmann, P., Voors, R., Kruizinga, B., Vink, R., Visser, H., and Levelt, P. F.: TROPOMI on the ESA Sentinel-5 Precursor: A GMES mission for global observations of the atmospheric composition for climate, air quality and ozone layer applications, Remote Sens. Environ., 120, 70-83, 2012.

Wang, H., Jacob, D. J., Le Sager, P., Streets, D. G., Park, R. J., Gilliand, A. B., and van Donkelaar, A.: Surface ozone background in the United States: Canadian and Mexican pollution influences, Atmos. Environ., 43, 1310-1319, 2009.
Wecht, K. J., Jacob, D. J., Wofsy, S. C., Kort, E. A., Worden, J. R., Kulawik, S. S., Henze, D. K., Kopacz, M., and Payne, V. H.: Validation of TES methane with HIPPO aircraft observations: implications for inverse modeling of methane sources, Atmos. Chem. Phys., 12, 1823-1832, doi:10.5194/acp-12-1823-2012, 2012.

Wecht, K. J., Jacob, D. J., Frankenberg, C., Blake, D. R., and Jiang, Z.: Mapping of North American methane emissions with high spatial resolution by inversion of SCIAMACHY satellite data, J. Geophys, Res., 119, 7741-7756, doi:10.1002/2014JD021551, 2014.

Wennberg, P. O., Mui, W., Wunch, D., Kort, E. A., Blake, D. R., Atlas, E. L., Santoni, G. W., Wofsy, S. C., Diskin, G. S., Jeong, S., and Fischer, M. L.: On the sources of methane to the Los Angeles atmosphere, Environ. Sci. Technol., 46, 9282-9289, 2012.

Worden, J., Kulawik, S., Frankenberg, C., Payne, V., Bowman, K., Cady-Peirara, K., Wecht, K., Lee, J.-E., and Noone, D.: Profiles of $\mathrm{CH}_{4}, \mathrm{HDO}, \mathrm{H}_{2} \mathrm{O}$, and $\mathrm{N}_{2} \mathrm{O}$ with improved lower tropospheric vertical resolution from Aura TES radiances, Atmos. Meas. Tech., 5, 397-411, doi:10.5194/amt-5-397-2012, 2012.

Wunch, D., Wennberg, P. O., Toon, G. C., Keppel-Aleks, G., and Yavin, Y. G.: Emissions of greenhouse gases from a North American megacity, Geophys. Res. Lett., 36, L15810, doi:10.1029/2009GL039825, 2009.

Xiong, X., Barnet, C. D., Maddy, E., Sweeney, C., Liu, X., Zhou, L., and Goldberg, M.: Characterization and Validation of Methane Products from the Atmospheric Infrared Sounder (AIRS), J. Geophys. Res., 113, G00A01, doi:10.1029/2007JG000500, 2008.

Xiong, X., Barnet, C., Maddy, E. S., Gambacorta, A., King, T. S., and Wofsy, S. C.: Mid-upper tropospheric methane retrieval from IASI and its validation, Atmos. Meas. Tech., 6, 2255-2265, doi:10.5194/amt-6-2255-2013, 2013.

Zhang, Y., Jaeglé, L., van Donkelaar, A., Martin, R. V., Holmes, C. D., Amos, H. M., Wang, Q., Talbot, R., Artz, R., Brooks, S., Luke, W., Holsen, T. M., Felton, D., Miller, E. K., Perry, K. D., Schmeltz, D., Steffen, A., Tordon, R., Weiss-Penzias, P., and Zsolway, R.: Nested-grid simulation of mercury over North America, Atmos. Chem. Phys., 12, 6095-6111, doi:10.5194/acp12-6095-2012, 2012.

Zhao, C., Andrews, A. E., Bianco, L., Eluszkiewicz, J., Hirsch, A., MacDonald, C., Nehrkorn, T., and Fischer, M. L.: Atmospheric inverse estimates of methane emissions from Central California, J. Geophys. Res., 114, D16302, doi:10.1029/2008JD011671, 2009. 